\title{
TELEVISION IS NOT RADIO: Theologies of Mediation in the Egyptian Islamic Revival
}

\author{
YASMIN MOLL \\ University of Michigan \\ (iD) http:/ / orcid.org/0000-0001-5179-8540
}

On a cool November evening in 2010, at Saqiat al-Sawy, a cultural center in an upscale Cairo neighborhood, the Egyptian Islamic television preacher Mustafa Hosny convened a religious seminar titled "Technology and Godliness." AlSawy hosts many events, from jazz concerts to smoking cessation clinics to, for a brief time after the 2011 revolution, political debates. Dressed in dark jeans and a Nehru-collared shirt, Hosny spoke in a seemingly improvisational manner as young men and women in their late teens and early twenties sat watching his image on large screens. Everything about this seminar - from the venue to the mixed-gender seating to Hosny's stylish clothing — was calculated to subvert stereotypes held by both secularists and religious revivalists about what participating in the Islamic da'wa, or pious outreach, movement entails.

On the stage, Hosny announced his collaboration with a famous pop singer and actor, Khalid Selim, to record an album with the same title as Hosny's most recent Islamic television program. The musical incarnation of the da'wa program consisted of ten songs by Selim, intercut with pious exhortations by Hosny on godliness, rububiya. Selim, with his chiseled physique, chart-topping tunes, and heartthrob celebrity made for an unlikely da ${ }^{\prime} w a$ partner. And that was precisely what made him attractive for pious outreach. Working with him laid down yet 
another stone on the ambitious road television preachers like Hosny were paving: changing what Islamic media looks and sounds like.

Hosny is one of Egypt's al-du'ah al-gudud, or New Preachers, so named because their television preaching styles are unprecedented within the country's forty-year Islamic Revival. Between 2010 and 2013, I conducted fieldwork with Hosny and his media team in the Cairo studios and offices of Iqraa, a transnational Islamic satellite channel. Established in 1998 by a Saudi media mogul, Iqraa promotes a "centrist Islam" (islam wasati) as a bulwark against both secular Westernization and religious dogmatism. For Iqraa producers, the channel's moderation is evidenced by its broadcast of preachers from different, at times mutually antagonistic, Islamic trends, whether Sufism, Salafism, or political Islamism. Despite this on-screen diversity, within Egypt Iqraa is best known for launching the careers of the country's most prominent New Preachers, the trio of Amr Khaled, Moez Masoud, and Mustafa Hosny, all of whom attract youth who would not normally tune into an Islamic program.

As their Cairo viewers explained to me, these preachers matter to them both because of what and how they preach. The New Preachers appropriate genres from dramatic serials to music videos to American televangelism to create novel forms of religious media at once edifying and entertaining. In doing so, the New Preachers and their producers straddle distinct standards of moral probity, commercial success, and sensuous pleasure as their programs expand what counts as "Islamic media" and why. ${ }^{1}$ It is precisely this innovation in da'wa-and its underlying theological claims and associated moral sensibilities - that has earned the New Preachers much criticism from their equally popular Salafi-Wahabi counterparts in the piety movement.

Salafi-Wahabism is a heterogeneous orientation bringing together individuals and groups that each lay claim to the true Salafi way (al-Rasheed 2006; Lauzière 2016). In Egypt, the most admired Salafi television preachers claim authority as students of the influential sheikh Nasir al-Din al-Albani. ${ }^{2}$ These preachers achieved renown in the 1990s for their cassette sermons (Hirschkind 2006). The New Preachers disagree with Salafi teachings on theological grounds. They consider Salafi teachings un-Islamic in the most fundamental sense: they do not reflect God's will. Such an evaluation differs from that of some Egyptians outside the piety movement, who view Salafi norms as aspirational even while bemoaning their own incapacity to fulfill them (Schielke 2009). It also diverges from the critiques of both secular nationalists and political Islamists in Egypt, who disparage the piety movement's focus on ritual practice (Mahmood 2005). Like their Salafi 
counterparts, the New Preachers understand ritual worship as an ineluctable component of creating the capacity for virtue. They consider the popular Egyptian refrain that "religion is in the heart" (al-din fi al-qalb) — a matter of interiorized feelings or inherited identity — a misapprehension of the embodied discipline that religion demands. ${ }^{3}$ Questioned here is not Salafis' emphasis on ritual practice but their ostensible failure to grasp what the virtues cultivated by such practice entail in terms of social interaction and individual transformation. This failure comes from an incorrect understanding of what forms of life are pleasing to God.

New Preachers like Hosny envisage their media as prophylactics against Salafi revivalism, whose sermonizers now have their own satellite television platforms (Field and Hamam 2009) and a significant online presence (Hirschkind 2012). The problem, however, is that Salafism's pious promoters and secular critics alike conflate its erroneous norms and lifeworlds with Islamic piety itself. Consequently, what the da'wa movement needed was nothing less than a "reconstruction of what piety looks like" ('iyadat siyaghat shakl al-tadayyun), as Hosny likes to put it. The New Preachers' desire to "reconstruct" religiosity involves the very forms of its mediation. The discursive and aesthetic possibilities afforded by televisual broadcast technologies prove key to this project.

This article examines how media claiming a pious mandate are objects of both on- and off-screen contention within the Islamic television sector, offering an important window onto Islam's competing theologies and the internal struggles they engender among revivalists. In what follows, I trace how the New Preachers celebrate and champion what they call "innovation" (ibda') in television preaching, while their Salafi rivals condemn and censure these same practices. As with the Islamic tradition generally, the different currents of Egypt's piety movement are typically analyzed as part of a singular moral project defined by its opposition to secular publics and subjects. In contrast, I argue that rival forms of televisual da'wa within this movement proceed from conceptions of piety that differently configure the religious and the secular through both competing doctrinal discourses and media practices. I show how the New Preachers work through the Qur'anic notions of ta 'aruf, mutual human knowing, and fitra, divinely created human nature, to promote as Islamic da'wa appropriations of Western media forms, while Salafi revivalists appeal to precepts barring bid 'a, religious innovation, to proscribe such da'wa as un-Islamic.

In making this argument, I invite attention to the secular and the religious as unstable formations not only within our analytical accounts (Starrett 2010; Winegar 2014) but also within the piety movement itself. I suggest that one way 
to think about the "authorizing processes" (Asad 1993, 37) through which sensibilities, practices, or beliefs, including those about media, come to be religious or secular — and what this means for how to live an Islamic life — involves recasting these as matters of continually evolving theological contention. Anthropologists have not paid enough attention to theology (Robbins 2006; Robbins and Engelke 2010), even as the latent (Protestant) theological presuppositions of anthropology's analytical categories have been carefully excavated. The relative dearth of ethnographic interest in theology, including in the ways that scriptural monotheistic religions frame theology as the bedrock of ethics (see Keane 2014), is puzzling considering that theology does not exist in an abstracted dogmatic vacuum but constitutes believers' situated attempts to think through how they should apprehend and live in the world, including in the everyday. ${ }^{4}$ By ignoring theology qua theology, we elide not only how theological traditions provide Muslims with ongoing resources to address new moral problems but also how Muslims seek to counteract, through theology, moral problems they perceive as engendered by erroneous theological constructs in the first place. $^{5}$

Religious practitioners reconfigure the Islamic tradition through engagement with the variety of normative regimes they encounter as modern subjects. Such reconfigurations are intrinsic to the production of a discursive tradition, rendering the notion of an invented tradition analytically suspect (Asad 1996). At the same time, the idea of an invented tradition has traction for religious adepts themselves. During fieldwork in Egypt, many of the accusations exchanged between rival revivalists hinged on the claim that the opposing group was "inventing a new religion" (biyikhtur' $u$ din gadid). My point is not the usual one that the Islamic tradition can sustain a multiplicity of ethico-religious positions, but rather that such positions often draw the boundaries of the religious and secular so differently as to foreclose the possibility of mutual acceptance or, indeed, coherence. These internal differences put in sharp relief the passionate contention among pietists themselves not only over particular reconfigurations of the tradition but, more fundamentally, over what makes a form of life Islamic, a sensibility virtuous, a practice pious. In this way, debates about Islamic media are constitutive of the very ethico-theological divisions they articulate, inciting continuing differentiation and distinction within the piety movement. Focusing on these divisions allows for ethnographic engagement with how Muslim adepts critique religious differenceand the difference that religious critique makes - beyond the imperatives of secular power. ${ }^{6}$ 
I integrate these concerns from the anthropology of Islam with the by now established ethnographic attention to the intersections of religion and media. Following a broader turn to media as social practice (Ginsburg, Abu-Lughod, and Larkin 2002) and from media anthropology to the anthropology of mediation (Boyer 2012), this research has considered the various ways religious practitioners discipline and train their senses through media. Relatedly, another focus has been on how media make religious life itself both possible and possible in new ways. ${ }^{7}$ In contrast, I am interested in looking at how media content and aesthetic forms are construed as religious in the first place. Within the Egyptian piety movement, different Islamic doctrines and precepts are elaborated in new ways to address emergent ethical dilemmas centered on media and mediation, on the specific manipulations of particular communicative technologies and what these represent. We can characterize these elaborations as theologies of mediation. Such theologies scrutinize meta-level claims about the means and ends of media from a perspective oriented toward divine revelation, one in which media are inextricably tied to claims about what godliness demands. Here, media are assumed to be objects of prescriptive divine address, and hence of moral discernment and judgment. These normative ideas about what divinely authorized practices of media-making entail frequently go beyond questions of religious permissibility to encompass broader interpretations of cultural diversity, human nature, and everyday life. Such contested theologies ground divergent evaluations of what makes media "Islamic" within Egypt's da'wa landscape. ${ }^{8}$

What interests me is not the veracity or desirability of these evaluations, but rather how they create competing forms of moral distinction within the piety movement through theologically reasoned narratives of difference. These narratives offer an ethnographic vantage point onto internal revivalist critiques that frequently caricature the opposing side in religious polemic. Such caricaturesthe New Preachers as morally "lax," Salafi preachers as "unimaginative" - take form through wider deliberations about what it means to lead an Islamic life, yielding insight into the diverse and often competing anxieties and desires animating religious revivalists. In such heated debates both sides tend to amplify their differences while overlooking areas of overlap; I focus precisely on the implications of these exaggerations and erasures for understanding how participants in the piety movement create and receive new forms of media. Indeed, while it is important not to uncritically reproduce such self-narratives at the analytical level (see Larkin 2015, 67), centering ethnographically the normative work such narratives do allows for a better understanding of how specific media become "Is- 
lamic" for some Muslim adepts but not for others. It also means restraining, to some degree, our own anthropological impulse to unmask such internal accounts as inaccurate in order to take seriously what is at stake for our interlocutors in such descriptions, including the ways in which they matter within the social world of Islamic television.

To that end, in the first sections of this essay I look at how the New Preachers and their producers make new forms of television $d a^{6} w a$ as an alternative to what they feel to be the mediocre, unimaginative, and incorrect programs of Salafi preachers. I show how their media strategies embed specific religious assumptions about human nature, pious discipline, and what they call "ordinary life." From there, I examine the ways Salafi critiques of such da'wa projects are informed by longstanding theological precepts that have gained new salience in response to emergent (and, from this perspective, troubling) media forms claiming a religious mandate. These normative constellations evaluate Western entertainment as ineluctably subversive of godly attention and unsuitable for religious publicity. I conclude by thinking about how a focus on Islamic revivalism's internal fractures can complicate the politics of ethnographic critique.

\section{DAZZLING $D A^{`} W A$}

Islamic preachers have appeared on Egyptian television since the 1960s, with some such as Sheikh Sha'arawi achieving a level of popularity that remains unrivaled after his death (Chih and Mayeur-Jaouen 2002; Brinton 2015). For the transmission of supposedly correct understandings of Islam to citizens, Egyptian state television not only broadcasts religious content such as Friday mosque sermons and Qur'anic exegeses but also dramatic serials that impart a nationalist vision of "good Islam" (Abu-Lughod 2004). In the late 1990s, however, changes in political economies and media regulations made possible the private ownership of television channels in the satellite sector, thereby ending the state's monopoly on television as an outreach platform.

Since then, panic has characterized Egyptian public discourses about transnational satellite television. Local observers describe in dystopic terms the growth of privately owned channels and their corrosive social effects. Religious channels (al-qanawat al-diniya) are the main objects of these critiques despite being numerically, financially, and in terms of viewership minor players in the satellite sector. ${ }^{9}$ During my fieldwork, I clipped hundreds of editorials and articles from newspapers, both governmental and oppositional, condemning Islamic television preachers as money-grubbing charlatans who might also be treasonous collabo- 
rators working for sinister foreign powers. These editorials - along with recent dramatic serials, films, and novels (Armbrust 2014)—lambast Islamic television preachers as instrumentalist and insincere, as tuggar din, merchants of religion.

Such critiques, whether coming from liberal and leftist intellectuals or the state's Islamic establishment, betray an anxiety about nonstate religious publicity that the producers I worked with at Iqraa found naive. At Iqraa, the problem was not Islamic television channels generally, but specifically Salafi television channels like al-Nas, al-Rahma, and al-Hikma. One of the issues was what Iqraa producers called "media professionalism," defined mostly in terms of care for high production values and innovation in programming formats. Salafi television channels, they lamented, were the equivalent of mom-and-pop shops: small, haphazardly run operations with no five-year plans or strategic visions beyond the promotion of a "narrow" interpretation of Islam. From their perspective, the narrowness of Salafi religiosity - its doom-and-gloom (gham wa ham) tenor and disconnect from everyday life — was reflected in the narrowness of its televised da'wa forms. Indeed, the problem with Salafi television preaching was not just its seemingly irrelevant message but its indifference to the medium of such messages. The Salafis treated television as if it were radio, complained Emad, a senior producer at Iqraa in Cairo. "I could give my back to the television screen or close my eyes, and my experience of the program wouldn't change," he elaborated. "Their notion of $d^{\prime}{ }^{\prime} w a$ is very conventional [taqlidi]: basically, a preacher just sitting in front of the camera and speaking."

Producers use the negative label conventional as a shorthand for programs adhering too closely to the genre of direct da'wa, da 'wa mubashira, often further glossed as "God-says/the-Prophet-said." Programs in this mold feature a preacher in a studio setting narrating Qur'anic stories or events from the Prophet's and his companions' lives, or else they pivot around moral exhortation, exclusively citing Qur'anic verses and Prophetic sayings. For the professionally trained directors, cinematographers, and editors I met, the reliance of Salafi television channels on this genre did not present opportunities for what they referred to interchangeably as "creativity" or "innovation." Creativity was indexed by an interest in including elements like dramatic acting, music, special effects, or even simply in shooting a program on location, as opposed to in an indoor studio. At other times, producers spoke of innovation in terms of both form and content. "We want to create religious media that is close to viewers' lives, not far from life like the Salafis," Emad put it once. "We can do this by using nonreligious tools such as songs or acting within the $d a^{\prime}$ wa program, but also by talking about 
things that matter to them, like dating, leisure, or studying.” For Islamic media producers like Emad, this reimagination of both religious discourse and its forms of presentation makes the programs of the New Preachers morally effective in an overwhelmingly secular media environment, secular here meaning avowedly indifferent to religiously reasoned strictures of broadcast permissibility. ${ }^{10}$

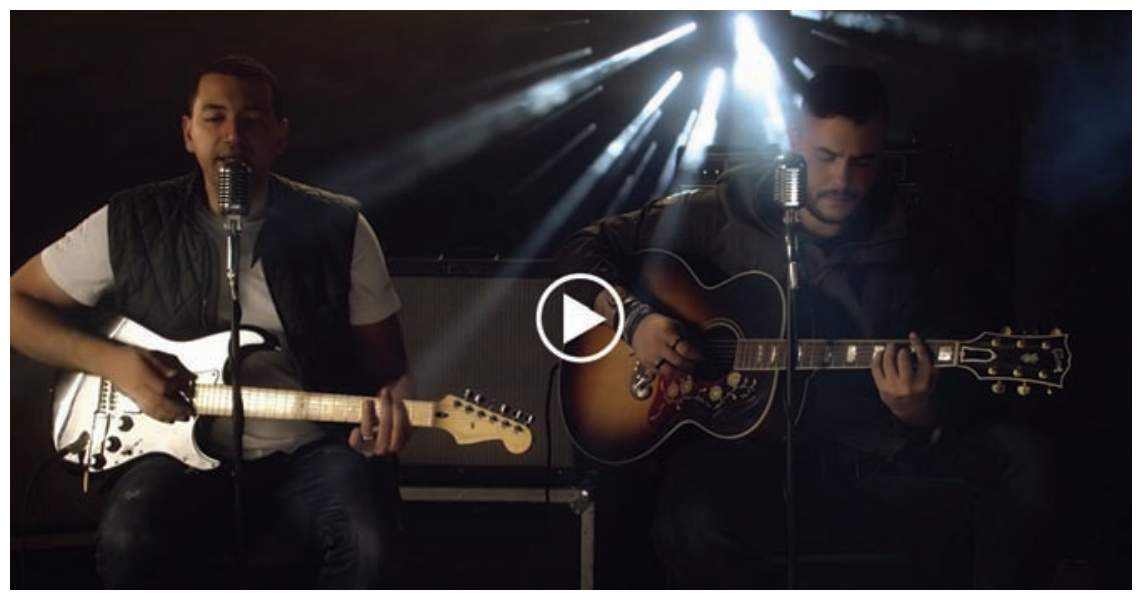

Video 1. Music video for "O Journey" (Arabic: Ya Rihla), released in 2016 by the preacher Moez Masoud. Masoud plays the guitar and sings in the video, which features Amir Eid, the lead singer for the Egyptian rock band Cairokee. Video courtesy of Moez Masoud.

Iqraa producers assume that viewers who watch Hosny's programs possess an intense interest in, and desire for, religious knowledge. Nevertheless, to attract and retain such viewers the producers feel that they must create programs that can compete with nonreligious media in both production quality and entertainment value. For them, mainstream media is successful because it is mubhir, dazzling. Instead of da'wa mubashira, direct $d a^{\prime} w a$, these producers sought to promote da'wa mubhira, dazzling da'wa. Strategizing how to make their media enjoyable within the constraints of both "Islamic parameters" (dawabit islamiyya) and comparatively small budgets constitutes a key aspect of their work. Indeed, financial limits dictate that Hosny's team has to frequently adopt the very formats they abjure as conventional, with producers continually challenged to create dazzling segments within otherwise staid studio-based programs. To better understand the tastes and expectations of their audience so as to more successfully extrapolate what they might find appealing to watch, Iqraa producers marshal research and data tools like focus groups, social media polls, and postseminar questionnaires. Class becomes important here. Iqraa producers presume that their viewers care 
about the "look" of the program because they are "cosmopolitan," universityeducated, and upper-middle- to middle-class. ${ }^{11}$ Such viewers have "seen it all," so to dazzle them - the thinking goes - a program must be as visually sophisticated as the entertainment media they regularly consume, whether Hollywood blockbusters, music videos, or reality shows. Instead of dazzling these viewers, Salafi da'wa programs confirm secular stereotypes of religious media, and by extension of religiosity itself, as intolerant, irrelevant, and, perhaps most damningly, boring.

Echoing the criticism of Egyptian secularists - who also frame the New Preachers as "radical Islamists in sheep's clothing" (Winegar 2014, 455)—some academic observers see this concern with aesthetics, class, and viewership as evidence of commodification. In this scholarship, New Preachers such as Amr Khaled are lambasted for promoting an "air-conditioned Islam" or an "opium of the rich," an ersatz "Islam-lite" produced by a nefarious neoliberal logic (e.g., Bayat 2002; Haenni and Tammam 2003; Atia 2013). By contrast, here I want to take seriously how these preachers and their affiliated producers see innovation in television da'wa as a theological imperative oriented both toward this-worldly flourishing and otherworldly salvation. To be sure, as Jessica Winegar (2014) has argued, we need a thicker ethnographic contextualization of revivalists such as the New Preachers within changing political economies, class-based distinctions, and urban-rural divisions if we want to rethink pious subject formation beyond the binaries of secularism and Islamism. At the same time, it is important to recall that while Islamic media is constituted, often self-consciously and deliberately, through practices and discourses that transcend longstanding religious-secular dichotomies, pious media practitioners nevertheless take as axiomatic the possibility of creating media that is normatively Islamic, that is not itself indifferent to secular-religious distinctions. Indeed, while current scholarship argues for approaching the secular and the religious not as fixed essences in opposition but as categories coconstituted relationally (Asad 2006), this analytical framework differs from the internal understanding of Islamic revivalists, who do assume religious and secular worldviews to be products of irreconcilable epistemologies, one divinely sanctioned, the other not. My point, then, is that what gets ascribed to each worldview differs across the piety movement. While Salafi pietists condemn as secular da'wa media that resembles Western cultural forms, the New Preachers promote this same media as religious, reserving the label secular for media productions unconcerned with divinely defined limits, even as those limits are disputed on Islamic television channels themselves. 
Actually, contested parameters of permissibility are central to the evaluative criteria marshaled for determining the dividing line between the religious and the secular within Islamic television. Salafi revivalists judge their New Preaching counterparts as stealth secularizers because they argue for the Islamic validity of what the Salafi tradition holds to be manifestly prohibited. By doing so, New Preaching da'wa instills Western secular norms even while erroneously claiming a religious mandate. For their part, the New Preachers hold their own da'wa projects as commensurate with Islamic attachment and, in fact, more faithful to the demands of pious commitment than those of their Salafi rivals. They argue that by upholding norms repellent to most people, by forbidding what God actually permits, Salafism renders secular lifeways more attractive to Muslim youth. As we will see, these differing arguments over what the Islamic tradition permits or prohibits are not theologically neutral but are made legible through contested doctrines that enact distinctive imaginaries of what a virtuous life entails and the media forms it authorizes. These imaginaries are in turn linked to changing practices and structures of practical knowledge within the social world of Islamic television production.

\section{KNOWING ONE ANOTHER}

The producers I worked with on Hosny's Iqraa team could be deemed promiscuous in terms of making Islamic media. Questioning the assumption that "different publics each have their own circulatory modes, their own discursive forms, so that one can neatly be separated from the other," Brian Larkin (2008, $104,105)$ uses promiscuity as an analytical trope to think about instances "when one public takes the discursive forms used to constitute another public." He traces the ways in which the South African Islamic preacher Ahmed Deedat appropriates the rhetorical forms of the Christian preachers he debates to debunk them on their own home turf. Such promiscuity has a long history within da'wa movements, with historians showing how the now taken-for-granted spaces and techniques of Islamic pious propagation across diverse Muslim societies often took direct inspiration from the colonial-era projects of Christian missionaries (Green 2014), including in Egypt where Islamist organizations like the Muslim Brotherhood were determined to "fight [missionaries] with their own weapons" (Baron 2014, 198).

The impetus behind this appropriation is reworked in the revivalist circles I researched to go beyond skilled instrumentality and, indeed, beyond a desire to convert or confound the conversion attempts of others. Borrowing is reasoned as 
a moral good grounded in the Qur'anic ideal of ta'aruf. Ta'aruf is a word that is difficult to translate, but it points to the active process of getting to know and communicating with others, to mutual engagement across various kinds of human difference. According to the interpretations offered to me, ta'aruf as an ethical orientation is compelled by the fact of human diversity and interdependence, following the Qur'anic verse (49:13): “[We] have made you into nations and tribes so that you might come to know one another [li-ta'arafu]." This diversity is itself indicative of divinity, for did God not say that "among His wonders is the creation of the heavens and the earth, and the diversity of your tongues and colors" (Qur'an 30:22)? The revivalists I worked with distilled this theological construal into the practical virtue of insaf, or fairness and evenhandedness.

"It is part of our tradition to learn from others," Emad put it to me, "no matter their religion or beliefs.” He invoked Qur' anic verses and Prophetic sayings as evidence that Muslims, enjoined to practice insaf, could adopt from any group or source what is of "benefit." We were discussing Salafi reactions to Hosny's first television da'wa program after the 2011 revolution. The program had focused on equipping viewers with the skills and ethos needed to build the "New Egypt" by showcasing exemplary individuals, including foreign non-Muslims and Egyptian Copts. This indifference to religious difference earned the program much criticism from Salafi preachers for whom a non-Muslim, as a matter of doctrine, cannot serve as a role model for Muslims. Emad argued that by denouncing as un-Islamic the positive appropriation of practices or ideas originally put forth by non-Muslims, Salafi theology incorrectly narrows the historical openness and creative adaptability of the Islamic tradition - which was, he went on, what had allowed Islam to spread across an extraordinary diversity of societies in the first place.

This adaptability is also exemplified by what my interlocutors held up as the most powerful "media text" (nas i 'lami) of all: divine revelation. After all, God says: "And never have We sent forth any apostle otherwise than [with a message] in his own people's tongue, so that he might make [the truth] clear unto them" (Qur'an 14:4). While God's truth is absolute, the revivalists I worked with explained that this truth must be conveyed within shifting human lifeways. The Prophet himself had utilized all the media technologies at his disposal in his own da'wa, tailoring it to his face-to-face addressees. Indeed, every prophet conveyed God's message in not just the language of his people, but through their prized media. Moses performed magical feats for a society that valued that; Jesus healed the sick at a time when people were plagued by disease; Mohammad's miracle was the Qur'an itself, whose linguistic inimitability overwhelmed a society that 


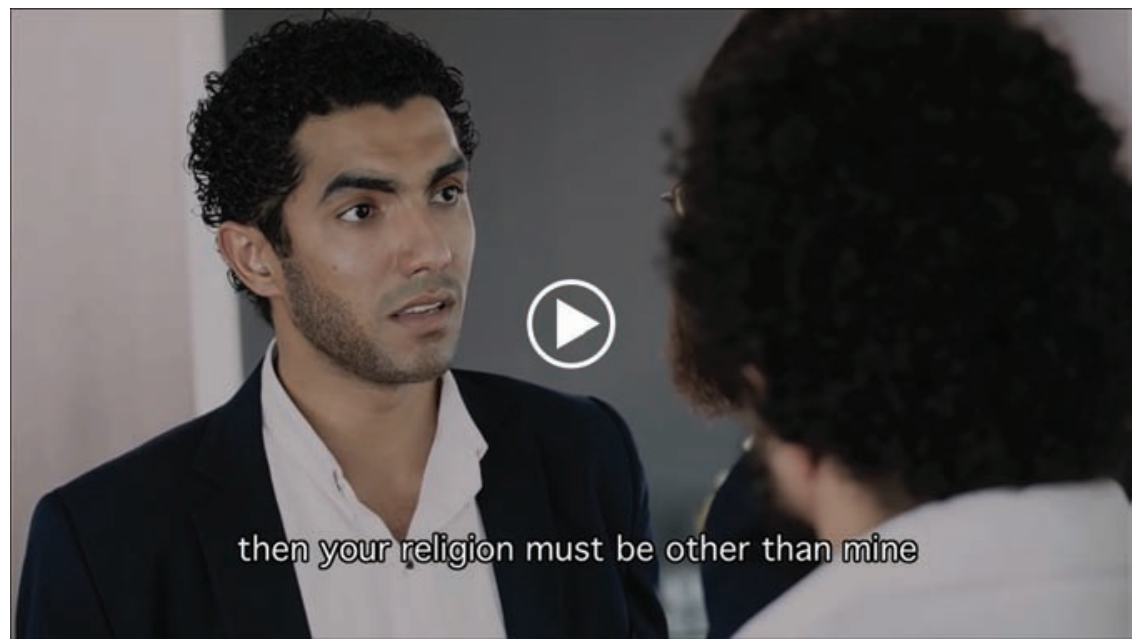

Video 2. A scene from Moez Masoud's 2013 television drama/da'wa series "Satanic Steps" (Arabic: Khatawat al-Shaytan), which focused on the Qur'anic imperative of ta'aruf. Video courtesy of Moez Masoud.

esteemed poetic expression. And even then, the Prophet did not always rely on reciting the Qur'an in his own da'wa; he sometimes told stories, as does God Himself in the Qur'an. Following these divine and prophetic models, the Islamic preacher has to convey God's eternal message in whatever medium resonates best with its current earthly recipients. For these revivalists, medial contingency (and hence diversity) is not only a historical fact but also an ongoing providential mandate.

This theology of mediation is implicit to the religious publicity efforts of other Islamic television preachers; for example, the Indonesian Aa Gym understood his mission in terms of "rebranding" Islam to make it accessible to his middle-class audience (Hoesterey 2016). It also goes beyond Islamic revivalism; British evangelicals, operating in a secularized milieu that viewed religiosity as "difficult and dull," premised their innovative Biblical outreach projects on the idea that "Christ spoke the language of the culture he was in" (Engelke 2013, 68, 27). For the New Preachers, the language of the culture - and thus the necessary form of religious renewal — is entertainment. To be sure, the producers I worked with at times overstated their own innovation in ways that both neglected continuities with older revivalist aesthetics and the constraints posed by limited budgets. But the fact remains that the production practices I observed were motivated by the assumption that the mediation of $d a^{6} w a$ in new and unexpected forms is germane to its success in moving Muslims to greater piety. The challenge is 
advancing this da'wa strategy within a revivalist context long shaped by a powerful counterarticulation of what makes media Islamic, one that hinged on repudiating entertainment forms, including the "dazzlement" (Hirschkind 2006, 183) they engender. It would be a mistake, however, to understand these two da'wa orientations as simply holding divergent views about which aspects of modern entertainment are compatible with a godly society; at issue here is what dispositions, modes of comportment, and ideals constitute such a society in the first place, not merely what media forms are conducive to its flourishing. As I will explore in the following two sections, the struggle between the New Preachers and their Salafi counterparts over the religious validity of appropriating Western media forms are located within wider theological constellations made to speak to different understandings of divinely created human nature and the role of human mediation in relation to revelation.

\section{TIRED OF RELIGION}

Back at the al-Sawy seminar, Hosny prepared the ground for introducing the album he had made with the pop singer Selim. Hosny is passionate about being a television preacher. As he tells it, one of his happiest moments came in 2004, when he saw himself for the first time on a video-editing monitor at Iqraa. He shed a few tears then, because he realized that his lifelong dream of trying to get as many people as possible to "taste the sweetness of faith" was being fulfilled. This had been Hosny's ambition from a young age. As a high school student, he would tape-record or take notes during mosque sermons and lessons, spend hours committing to memory what he had learned, and then eagerly preach it back to his friends as they passed the evening in the manner favored by most middle-class teenage boys: milling around their neighborhood kiosks sipping soft drinks, music blasting from dented parental cars. The lessons he learned performing for this irreverent, hard-to-please audience proved foundational to his later success on television. One of these lessons was that you cannot sternly scream love for God into most people; far more effective is gently and gradually creating this love by making religion attractive and relevant to them, fun even, and modeling the constant accessibility of godliness to even the most morally lax.

In the late 1990s, however, when Hosny was in his early twenties, it felt like being religious meant that one "couldn't have an ordinary life-it meant having to cancel out 99 percent of your life," he told me. Hosny and his producers at Iqraa define "ordinary life" (al-hayaa al- 'adiya) largely through participation in the leisure activities available to middle-class urban youth: going to the cinema, 
spending time at the beach in the summer, playing backgammon in coffee shops, listening to music while cruising. The Salafi preachers popular at the time- the "cassette sheikhs," Hosny sometimes calls them, referring to the medium on which their sermons first circulated - promoted as pious a sensibility that shunned such activities as morally corrupting. These preachers had become virtually synonymous with the Islamic Revival. From Hosny's perspective, this conflation proved problematic, because the norms Salafi revivalists propagated were incorrect, unnatural even. The hegemony of these norms within $d a^{\text {' } w a ~ c i r c l e s ~ m e a n t ~ t h a t ~ t h e ~}$ visibility of pious commitment had ironically made godliness more difficult to achieve among "ordinary youth" (al-shabab al- 'adi), who now would never even consider the possibility of becoming more religious.

Hosny told the young Egyptians who had come to see him in person at alSawy that many participants in the da'wa movement had adopted a holier-thanthou attitude, alienating the very people most in need of guidance. From this perspective, Salafi norms created cleavages between those who consider themselves "religious" mutadayyinin, on the one hand, and, on the other, the rest of society, seen by the former as moral failures. Salafi pietists have become, Hosny lamented, an enclave "far away" from the rest of society. This separation misses what godliness demands: a continual commitment to helping people find ways to be pious within the everyday idioms and rhythms of the present worlds they inhabit, not in the annihilation of these worlds. Hosny questions here not only the substance of the Salafi counterpublic — its sensibility, sociability, protocols of address, topics of concern - but the very premise of a counterpublic as a normative ideal. A counterpublic can never, from his vantage point, be Islamic.

Subverting this counterpublic was one of Hosny's aims in working with Selim, an entertainer with wide mainstream appeal and no previous links to the Islamic Revival. Hosny also ventured into largely uncharted territory in another way with the album, bringing together two things his Salafi detractors felt to be incommensurable: music - instruments and all — and piety. Against Salafi orthodoxy, the New Preachers presented the question of the permissibility of instrumental music as open to a range of jurisprudential opinions, all of them religiously legitimate despite Salafi claims to the contrary. The choice of which opinion to follow was ultimately a question of individual conviction. To accommodate this range, Hosny planned to release two versions of the album, one with instrumental music and one without. In contrast, Salafi preachers argued on several television programs dedicated to rebutting such claims that the matter was not open to disagreement in the first place. The reasoning of Islamic scholars, however 
learned, could not trump what they felt to be “clear” Qur'anic or Prophetic texts prohibiting this music, stating that God will hold Muslims accountable for their adherence to these texts, not for their commitment to mere human opinion.

As he stood on the stage in al-Sawy, Hosny played to his audience a few songs from the album. The music reverberated over the blue-black waves of the Nile. At the end of each song, most of the listeners applauded. But mixed in with the enthusiasm was a dash of skepticism. It expressed itself that evening in the form of a question scribbled on one of the small pieces of paper that uniformed volunteers passed up in batches to Hosny. Instead of working with a pop star, why had Hosny not collaborated with an exclusively Islamic devotional performer (munshid islami)? Looking up from the paper, Hosny walked over to the edge of the stage.

"We can't be here," he said, pointing to his feet, "and the rest of society over there." He gestured to the opposite edge of the stage.

If we had used an Islamic munshid, only the pious would have bought the $\mathrm{CD}$ and these people are tired of religion themselves. They want to hear some music! When a pious guy . . . hears the latest song by [pop star] Amr Diab, he makes a big show of being morally offended, but he is tapping his foot to the beat. But the balanced person [al-insan al-sawi] who attends religious lessons but also has fun, he doesn't have this hunger, so when he . . . hears this type of music, he is unaffected because he already has alternatives to listen to. And that is our goal with this album, to create an alternative.

Within this logic, adopting the largely Westernized aesthetics of Egyptian popular culture made manifest the mutuality of ta'aruf as both an important aim for new forms of Islamic media in a deeply polarized society and an intrinsic quality of the life such media promoted as godly. But the practical feasibility of ethical living in the everyday depended on the existence of entertainment options responsive to divine dictate. To distinguish this kind of cultural production from one indifferent to religious convictions, producers I worked with used the shorthand alfann al-hadif, literally, "purposeful art," better glossed in English as "ethical entertainment." A similar emphasis on making and consuming morally correct leisure has become prevalent over the past decade within Islamic activist circles in both Muslim-majority societies and the West (van Nieuwkerk 2011; Deeb and Harb 2013). Within Egypt, the New Preachers have advocated for the religious permissibility of these kinds of artistic productions and contributed to their grow- 
ing currency among urban middle-class participants in the Islamic Revival. Grounding such advocacy is a particular theological ontology of human nature, one that judges Salafi norms unnatural.

A few days after the album's launch, I met up with Hosny for an interview. I asked him how he reasoned through the idea that leisure in the Islamic tradition is not necessarily predicated on a disciplinary end (hadif tahzibi). He replied:

One of the characteristics of human nature is boredom. We don't like to just do one thing all the time. So if religiosity just means I have to pray all day, I will get bored [hazha']. If being religious means I have to recite the Qur'an all day long, I will be bored. But naturally Islam is comprehensive of all aspects of life. To have fun is to be godly, otherwise I would have to draw far away from God, have fun, and then come back to Him, which doesn't make sense.

In this theology of attention, being bored or remaining unmoved by religious speech — whether by preachers talking about the Qur'an or by listening to the Qur'an itself - is not due, as some sermonizers would have it, to an inadequate religious formation (Hirschkind 2006, 34) but to the nature of human beings, to the way God created us. Even the most pious would be unable to pay attention for more than a few hours without becoming distracted and restless, desirous of something else to break the monotony. Instead of judging these bored pietists as failures, cater to them, Hosny insisted. Give them a way to be religious in the world, not in struggle with the world. Give them, in other words, a way to be human as God Himself intended.

What needed to be promoted within the da'wa movement, then, was a tadayyun fitri, a natural religiosity, sustainable and realistic, its forms in keeping with, not opposed to, everyday life. Fitra is a Qur' anic concept referring to human beings' primordial, God-given nature. It names a positive disposition naturally inclined toward virtue. ${ }^{12}$ For my interlocutors, the norms propagated by Salafi revivalists are un-Islamic because they are fundamentally unnatural: they suppress our God-given desires. They would point to the Salafi prohibition on music as an example. "Even babies sway their bodies when they hear music," my colleagues on Hosny's team argued. That small children possessing beyond doubt an uncorrupted fitra would spontaneously move with the music gave evidence that this was a divinely sanctioned human inclination. Of course, Salafi preachers and religious scholars also subscribe to the idea of Islam as a natural religion; for them, 
however, the desire for entertainment is a corrupted one informed by a secular sensibility of what a normal life entails.

\section{THE MISGUIDANCE OF INNOVATION?}

For the Islamic media producers I worked with, Salafi television's shunning of entertainment media forms discredited it as too conventional. For Salafis themselves, however, this avoidance is precisely what made their channels morally authoritative. This argument was brought home to me early in my fieldwork during a conversation with Zaynab, a family acquaintance who equates television with the Salafi channels and da'wa with the Salafi preaching triumvirate of $\mathrm{Mu}$ hammed Hassan, Abu Ishaq al-Huwayni, and Muhammad Ya'coub. Zaynab enjoyed watching these preachers and felt they offered her practical guidelines for how to live virtuously in what she saw as a largely immoral society. She did not, however, value such preachers for offering "innovative" or "creative" programs; such criteria did not positively enter her viewing calculus the way they did for fans of the New Preachers. To the contrary: Zaynab knew that much of my interest in doing fieldwork at Iqraa stemmed from a curiosity about new forms of Islamic da'wa. From her perspective, however, the types of media Iqraa broadcast disqualified it from being an Islamic channel and indicated instead that the New Preachers were new and inventive in the pejorative sense of "inventing a new religion" (biyikhtu'ru din gadid). She urged me instead to research Salafi television channels because they "would never allow the sorts of programs Iqraa broadcasts. How can religion be combined with drama or music? Entertainment is the opposite of religion [al-fann 'aks al-din]." For Zaynab, "religion" here was synonymous with the truly Islamic — and thus with God's will, whether in matters of this world or the next - and her evaluation of what made entertainment antithetical to religion turned on the fact that she drew the boundaries between the religious and the secular differently than my Iqraa interlocutors. These boundaries, in turn, were doctrinally elaborated.

A few days after this conversation, Zaynab sent me an email with the subject line "the sheikhs' refutation of the New Preachers" with links to YouTube videos presenting Salafi rebuttals of the New Preachers. One was an excerpt from a sermon by al-Huwayni, in which he criticizes the New Preacher Amr Khaled for encouraging newly veiled actresses and singers - the so-called repentant artists (see van Nieuwkerk 2013) — to continue working in the entertainment industry and not abandon it altogether. Al-Huwayni lamented that the growth in Islamic television channels has given preachers like Khaled a platform to disseminate their 
erroneous ideas. "It is impossible for a man who has opened up even a single book of religious knowledge to say such words," protested al-Huwayni, claiming that all the Prophetic traditions Khaled uses as evidence for the permissibility of entertainment of whatever kind are fabricated.

These video and television sermons hew closely to the themes of their cassette precursors, which also criticized forms of mass entertainment as incompatible with virtue. As Charles Hirschkind (2006) shows, the disciplined audition of these cassette sermons enacted an Islamic counterpublic that distinguished itself from a secular sphere indexed most prominently by popular entertainment. Indeed, the need to listen to these tapes resulted from the perception that "the ever-more pervasive Western cultural forms - movies, television, music, dress styles, and protocols of sociability - insinuate themselves into the senses most directly, shaping the repertories of affect, gesture, and sensibility that animate and orient practical reasoning" (Hirschkind 2006, 213). The Islamic counterpublic constitutes a self-conscious response to the troubling sensibilities ostensibly attending such media forms. Within intrarevivalist contention, the counterpublic's constitutive assumption of a generalized, Westernized, secular media culture insidiously overwhelming Muslims acquires more specificity. Far from celebrating the aesthetics of televised popular culture and their ostensibly dazzling capacities for sensory engagement or affective immersion, Salafi preachers caution that the already pious are enjoined to judicious restraint, if not outright censure toward such media. What seems to disturb Salafi preachers like al-Huwayni, then, is that the New Preachers are not only introducing such cultural forms into pious spaces - the religious lesson, the da'wa program - but, even more egregiously, are arguing for their Islamic legitimacy. In doing so, the New Preachers are committing bid' $a$.

Bid"a —-literally, "innovation" — is extensively thematized within the Islamic tradition. Most Muslim theologians have categorized bid' $a$ in terms of the axiology of Islamic jurisprudence: obligatory, recommended, permissible, reprehensible, and forbidden. This scale could allow transformations in devotional practices, so long as they did not contradict the (variously interpreted) Qur'an, Prophetic tradition, or scholarly consensus. A bid'a could thus be praiseworthy or even obligatory for a Muslim to perform (Rispler 1991; Fierro 1992). A minority of premodern Islamic scholars rejected this scale, arguing that bid'a admits of no moral or legal flexibility, being inherently a misguidance (Winter 2009). This reasoning that bid' $a$ is intrinsically un-Islamic would be adopted by the eighteenthcentury reformer Muhammad Abdel Wahab, the eponymous founder of Wahab- 
ism, who made the eradication of bid' $a$ a central platform of his da'wa (Commins 2009). Grounding this effort was an understanding of piety as mimetic fidelity to the first Muslim community's practice of Islam, one ostensibly free of cultural contingency.

The ever-present moral perils of bid'a constitute a central theme of contemporary Egyptian Salafism, with many preachers opening their television programs with the Prophetic saying: "Beware of matters newly begun, for every matter newly begun is innovation [bid'a], and every innovation is misguidance, and every misguidance is in Hell." Salafi preachers warn their viewers against the errors of ahl al-bid 'a, "the people of innovation," that is, Muslims who claim to be following God's injunctions while in reality pursuing their own desires. In this way, the evaluation of practices or beliefs as bid' $a$ is not just a technical legal matter but goes to the heart of the question animating all participants in the piety movement: what is pleasing to God? Accusations of bid'a pragmatically work as a moralizing commentary that impugns a Muslim's devotion to divine desire and its embodiment in prophetic praxis. Within Salafi spaces, the New Preachers are frequently scorned as ahl al-bid'a.

Over the following several years, Zaynab would continue to send me links to Salafi critiques of the New Preachers, and I began systematically looking for episodes about the New Preachers aired on Salafi channels. There were many. For example, in 2010, the Salafi Al-Nas channel devoted several episodes to the New Preachers, in which preachers such as Mazin Sarsawi and Khalid Abdullah charged the New Preachers with being "secret Sufis" — Sufis being the epitome of ahl al-bid' $a$ in the Salafi creed — bent on creating what they called a "fake American Islam" that promoted secular norms. Polemics aside, what piqued my interest was the careful attention Salafi preachers devoted to the form of New Preaching programs as evidence of their moral turpitude. In one television episode after another, Salafi preachers argued that it was egregious to claim that entertainment forms could be either pleasing to God and the Prophet, or vehicles for praising God and the Prophet.

One Salafi preacher likened new forms of Islamic media to the act of "presenting halal meat in a pig's skin . . . this is presenting religion in an impure [najis] form." The impurity derives partly from such media frequently having music and singing and showing women on screen, all prohibited in Salafi orthodoxy. In addition, such content too closely resembles Western entertainment media, rendering Muslims liable to the sin of al-tashabuh bi al-kuffar, or imitating nonbelievers. Crucial to this evaluation is the specific interpretation of bid' $a$ within Salafi 
doctrine. As the mass mediation of Islam as “call” (see Spadola 2013) became the object of continual care and concern by Muslims generally, reformers of all theological and political persuasions continued a long tradition of moral inquiry into the religious permissibility of specific media technologies and forms in which the language of bid'a was germane. But what distinguishes modern Salafi theology is the extent to which illicitness can be a function of provenance, regardless of the intrinsic morality of the form or practice itself or, indeed, its novelty. The doctrines grounding such reasoning are multiple, but an important one is that of alwala' wal-bara', loyalty and disavowal, a standard topic of Salafi television sermonizing. In its first (albeit always contested) formulations, the doctrine enjoined that Muslims should show loyalty to their coreligionists and disavow the ways of non-Muslims. Modern Salafi Wahabi scholars recuperated the doctrine as a foundational tenet of Islamic orthodoxy that governed interaction and sociability not just between Muslims and non-Muslims but among Muslims themselves, seeing it as an important discursive tool in the ever-present struggle against bid' $a$ (Wagemakers 2009, 2012). Thus the doctrine became directed at Muslims engaging in un-Islamic practices, including their failure to abandon and declare their enmity to non-Muslim ways, evinced, for example, in their dress, comportment, and cultural references. Within the Egyptian piety movement, the broader moral logic animating this doctrine - that maintaining what its advocates saw as an "Islamic" distinctiveness is necessary to virtuous living and after-life salvation — would become criterial for Salafis' negative appraisals of New Preaching programs.

In one representative criticism, the outspoken Salafi preacher Wagdi Ghoneim wonders how the New Preachers could even consider themselves Islamic preachers when they neither look Islamic - being unbearded or insufficiently bearded - nor draw exclusively on the Qur' an and the Sunnah in their homiletics, marshaling instead references from popular culture to philosophy to poetry. "If [preachers] don't limit themselves to God-says/the-Prophet-said, you should know then that they are quacks," Ghoneim argues in a television program excerpted on YouTube. As we saw, this is precisely the da'wa form that Iqraa producers on Hosny's team abjure as boring and conventional. But for Ghoneim, for da'wa to be da'wa, it must exclusively adhere to this putatively unadorned discursive form.

Ghoneim's critique of the New Preachers prescriptively orients to divine revelation as possessing a moral efficacy completely autonomous of mediating human artifacts. The Qur'an as God's message to humankind does not need to be packaged, strategized, brainstormed, focus-grouped or, indeed, inventively 
mediated. It dazzles on its own. ${ }^{13}$ From this perspective, New Preachers continually calling attention to the medium of pious outreach as mattering, as something that needs deliberate and creative exploiting for a message-including a divine one- to be compelling or resonant to its addressees, is as egregious as their selfconscious appropriation of Western aesthetics. Such efforts to create new ways of doing da'wa-and, by extension, new visual and sonic expectations of pious publicity that resemble too closely that of secular culture-open the door to innovation in religious discipline, to bid ' $a$, and imply that the Qur' an is not enough to move humans to greater piety.

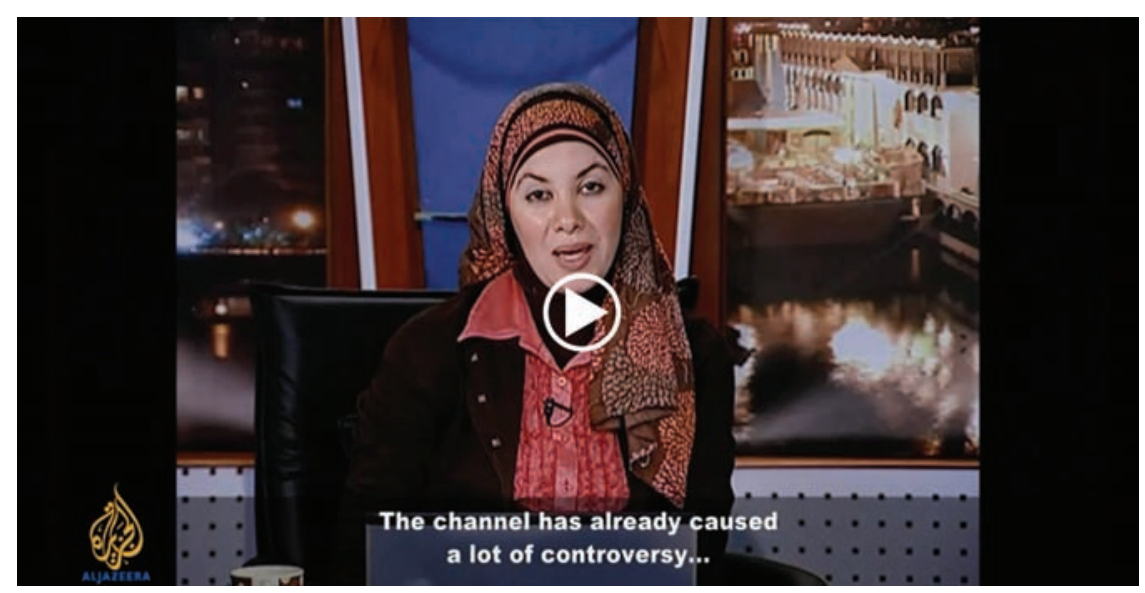

Video 3. Excerpt from the documentary Pop Goes Islam (2011), directed by Ismail ElMokadem. Here, Ahmed Abu Haibah, Amr Khaled's debut producer, debates the launch of his Islamic music-video channel with Sheikh Yusuf al-Badri. Abu Haibah is an influential advocate for new forms of Islamic media. Al-Badri was known for his high-profile court cases against "un-Islamic" intellectuals and cultural producers in Egypt. Video courtesy of Alegria Productions.

While the New Preachers also adhere to the orthodox doctrine of Qur'anic inimitability, they claim that the Qur'anic message nevertheless needs to be presented in ways that engage their target audience of middle-class urban youth. In a postmillennium globalized media environment, that means through entertainment. Doing so is in keeping with the Qur'an's own avowal of a single eternal message delivered via a variety of differently situated messengers and contingent forms across time. Da'wa practitioners should stay true to this divine dynamism in their own efforts to propagate God's final revelation. At the same time, the New Preachers share with their Salafi counterparts the assessment that the sensuous dimensions of entertainment are powerful and potentially morally perilous. 
In an episode in his 2012 Ramadan series Worldly Enchantments, strategically shot on location in dazzling Dubai and Istanbul, Hosny proposes that modern entertainment is beguiling: it entrances us, potentially corrupting our fitra. But it is precisely entertainment's power to affect us that makes its skilled exploitation ethically incumbent on Islamic preachers as professional promoters of piety. Song and sermon do not have to compete for the sensory attention of believers but can conjoin to amplify godliness. There are no qualms here about Muslims consuming religious media as entertainment or for leisurely distraction (Hirschkind 2006, 92) - that is precisely the goal.

This is not to say that Salafis' own investment in the changing communicative infrastructure of pious propagation is negligible. In an important way, the history of the Salafi Wahabi mission - and the enviable authority that the norms propagated by its adherents have come to enjoy within revivalist circles throughout the Muslim world — can be told through the changing technologies of mass publicity that Salafi revivalists have adopted with alacrity over the past two centuries, from the printing press to radio to television to digital media. More to the point, the rhetorical forms of Salafi sermons, notwithstanding their condemnatory substance, draw on disparate traditions, from political speeches to cinematic techniques to Sufism (Hirschkind 2006). In censuring the New Preachers as un-Islamic, Salafi preachers are neither self-deluded nor duplicitous about their own da'wa forms; rather, in common with other practitioners across religious traditions, they have come to see some forms of religious mediation (e.g., a sermon recorded on cassette or on camera) as not in fact mediated in any significant sense, as "immediate" (see Meyer 2011). ${ }^{14}$ Crucially, the New Preachers' own disparagement of the Salafis for conflating da'wa with direct moral exhortation exclusively citing the Islamic tradition's two foundational texts (God-says/the-Prophet-said) also hinges on an assumption that some television performances are more or less mediated than others. Recall Emad's lament that Salafi preachers approach television as if it were radio, exhibiting what he saw as a negligent indifference to the technical-aesthetic affordances of a medium at once auditory and visual. Unlike Emad, Salafi television preachers (and Salafi-identifying viewers like Zaynab) laud their programs as further evidence of their channels' promotion of "true Islam" through genuinely Islamic means, means avowedly untainted by religious innovation, especially innovation in the direction of secular cultural forms.

The point is that even if Salafi activists may in their own way be as promiscuous as their New Preaching counterparts, only the latter metadiscursively promote medial innovation through aesthetic appropriation as a theologically justi- 
fied — and, indeed, enjoined — form of persuasive religious outreach. The various doctrinal thematizations of Salafi objections to such a claim illustrate that contestations over the means of Islamic propagation are inextricable from internal disagreements over its ends. Indeed, the competing revivalist orientations described here are not just matters of varying rhetorical framing. They cut deep as they offer religiously grounded criteria for evaluating what makes media "Islamic," predicating distinctive ways of imagining and practicing piety. Disagreements about media become proxies for wider debates about what is essential to human nature and pious attachment and how one can be true to both given the everyday moral challenges of modern life, not least those posed by mass media.

\section{CONCLUSION: Whose Critique?}

Islamic revivalists see themselves as passionately concerned with leading a life pleasing to God and with calling others to do the same. But, as I have shown, while they profess their commitment to piety as the most significant aspiration of their lives as Muslims (and, indeed, in their view of any properly Islamic life), they do not share a singular pious sensibility. Salafi pietists repudiate Western cultural forms as incompatible with cultivating the attributes necessary for virtuous conduct, while their New Preaching counterparts embrace such forms in their television da'wa. This difference indexes competing formations of what an ethical life entails, foregrounding the ways in which the boundaries of the religious and the secular - and the sensibilities these boundaries authorize, the forms of life they sanction - are variously configured within the piety movement, even while its participants unanimously reject secularism as political doctrine. Attending to the internal contentions that these differences provoke requires attending to the fundamentally different conceptions of human flourishing and divine obligation that animate the piety movement. It is to approach the Islamic tradition as it matters to Muslims themselves: as theology, or "God-talk" (Chittick 2008, 221), broadly construed. By way of conclusion, I would like to think briefly about the stakes of such a recasting for questions of anthropological critique.

Salafi Muslims are the current abject Other in Western media and policy discourses on Islam. All too often, Salafi doctrines are dissected as gateways to violent ideologies and terrorist activities. ${ }^{15}$ Under such scrutiny, the mere fact of adopting pious norms that run counter to a conception of religion as a matter of private, interior faith is deemed problematic. Anthropologists studying conservative religious activists have highlighted the moral disgust felt by liberal and leftist scholars toward such groups, with Saba Mahmood (2005) memorably writ- 
ing of her visceral feelings of repugnance toward aspects of the piety movement she studied in Egypt. She proposes to make such feelings an object of inquiry with the aim of provincializing the secular norms that underpin them. In response, Samuli Schielke $(2015,92)$ argues that the normative impulses internal to religious power should also be interrogated given the "hegemonic normality" of such power in Egypt. From this perspective, an anthropological critique of revivalist norms creates space for taking seriously ordinary Egyptians' vacillation toward piety.

Importantly, both of these anthropological stances construct the piety movement as a domain for working out political and ethical differences largely external to the concerns of its practitioners. Framing the study of Islam as a challenge to “our own" secular understandings and values shifts attention from Muslim adepts' own struggles over the definition of the good and the nature of a life well-lived. Similarly, mounting an anthropological critique of the piety movement occludes an understanding of it as a diverse practice to which participants bring their own critical questions. That is, critique is something in which pietists themselves engage against each other.

This tendency to overlook internal struggle has become evident in a recent debate over the so-called everyday turn in the anthropology of Islam. The debate addresses how anthropologists should apprehend the relationship between ordinary life and piety, with one camp seeing the disciplinary stress on the everyday as indicative of "secular-liberal sensibilities" (Fadil and Fernando 2015, 61) and the other seeing it as a much-needed complication of pietists' own disciplinary aspirations (Schielke 2010). But the relationship between religious norms and ordinary life is precisely what is at stake for revivalists themselves in their own critiques of different forms of da'wa media. By debating analytically what religious adepts contest normatively, anthropologists neglect religiously grounded arguments about different forms of Islamic attachment in favor of religious-secular or pious-impious binaries, missing that these binaries are not stable but configured differently through God-talk. ${ }^{16}$ What the debate frames as an anthropological divide turns out to be a theological one.

Instead of worrying about what crypto-political sensibilities anthropological turns entrench or resist, we could ask what insights into religious life become possible when we shift our attention from the discomfiture of the anthropological observer to that of the anthropological subject. During fieldwork, I was repeatedly struck by the repugnance my interlocutors in the world of Islamic television production evinced toward the sensibilities animating their Salafi coparticipants. Another way to provincialize secular norms while remaining attuned to their 
religious correlates, then, might be to examine the local power dynamics of this (mutual) aversion as pietists struggle with each other over the definition of the Islamic. Such a focus avoids what Sherry Ortner (1995) has called "the problem of ethnographic refusal," one partly borne of "the impulse to sanitize the internal politics of the dominated" (Ortner 1995, 179) lest powerful external actors and the structural asymmetries reproducing their power be let off the hook. ${ }^{17}$ Our analytical frameworks would thus be attuned to the Islamic tradition as a constellation of contested practices and norms only legible as "Islamic" for some religious actors and not others. As we have seen, Islamic revivalists like the New Preachers, who are themselves wary of secularized formations of religiosity, nevertheless critique Salafism as promoting an unnatural religiosity. This does not mean that they discount Salafism; rather, they take it seriously in what for them is the most important way: theologically, as a rival foray into God-talk.

Anthropologists have recently called for taking God seriously as a "social actor" (Bialecki 2014, 38), while remaining methodologically indifferent to the question of God's existence. ${ }^{18}$ Such an ethnographic stance contrasts with theology, where there is little room for indifference to the ontological status of God on the part of the analyst. Unlike theologians, we as anthropologists routinely proceed as if God did not matter analytically, as if the divinely mandated relations of obligation that bind us to each other and to this earth should not shape socialscientific ways of knowing. While as teachers and researchers, we welcome religious perspectives in our classrooms and may privilege them in our ethnographies, in common with other disciplines in the global Western academy we seldom explicitly make religious warrants the basis of either our pedagogy or our theorizing, a situation that is itself partly the result of a complicated Christian theological history (Gregory 2012).

As anthropologists of religion, then, we are not really looking from the inside out, or at least not from the same inside as our pious interlocutors, even if our personal religious lives overlap significantly with theirs. By contrast, even when we question secular suppositions, we only do so from the secular presupposition of divinity as unnecessary to the labor of analysis. This holds even when the ethnographic terrain for this analytical labor is a theistic tradition. Put differently, when we study Islam anthropologically, Islam is not, in that process, our tradition, even when we are Muslim anthropologists. Our critical engagement with it is not an internal, normative one, one conducted within that tradition's own sources of authority and appeal. If we seek to be morally responsible in our analysis, we can argue about the Islamic tradition, but not with it, to repurpose 
an important provocation by Talal Asad (1995). This is less a point about insideroutsider positionality and more about how the telos of critique is inextricable from the shared premises that make arguing with something possible in the first place. For revivalists this would include recognition of divine agency in human history and acknowledgment of divinely defined limits to human action, even as what those limits are and what modes of being they authorize is precisely what internal critique seeks to ascertain.

One way to take God seriously anthropologically, then, is to pay attention to how religious subjects themselves do so, to trace ethnographically the social life of theology as a space of critical contestation. In the case of Egypt's Islamic Revival, an emphasis on internal critique invites us to notice the differing investments Muslims bring to the Islamic tradition, investments that stem from divergent imaginations of both what it means to be human and what God desires. Contests over what makes media Islamic are particularly revealing of these divergent theologies, not least because of their shared assumption that media-making constitutes an object of divine interest and adjudication. Set against the fractures of the piety movement, these theologies, including their mass mediation on satellite television, shape the means and ends of critique with stakes much higher than our own: attaining divine pleasure in this world and the next.

\section{ABSTRACT}

What makes media "Islamic"? Drawing on ethnographic fieldwork with Islamic television producers in Cairo, this article looks at the passionate contention within Egypt's piety movement over the development of new forms of religious media. I suggest that at stake in these mass-mediated debates over da 'wa (Islamic outreach) are conflicting theologies of mediation that configure the boundaries of the religious and the secular differently. This God-talk matters greatly to Islamic revivalists, who spend more time debunking each other than they do secularists. Attention to these internal critiques foregrounds the competing moral conceptions of human flourishing and divine obligation that animate Egypt's Islamic Revival. Indeed, focusing on the piety movement's internal fractures as God-talk allows for an ethnographic engagement with how Muslim adepts critique religious difference - and the difference that religious critique makes - beyond the imperatives of secular power. This focus, in turn, complicates the stakes of anthropological judgment. [media; theology; piety; critique; Islam; Egypt]

\section{NOTES}

Acknowledgments Jatin Dua, Tessa Farmer, Sherine Hamdy, Michael Lempert, Amira Mittermaier, Ram Natarajan, Andrew Shryock, and Ana Maria Vinea offered excellent feedback on various drafts of this article. I am grateful for their insights. Colleagues at the Uni- 
versity of Arkansas, Cornell University, Leiden University, the University of Michigan, and Northwestern University (especially Jessica Winegar), as well as at the 2017 annual meeting of the American Anthropological Association in Washington, D.C. (particularly Katherine Ewing) shared many useful suggestions on this material. Cultural Anthropology's anonymous reviewers gave the gift of critique that was at once challenging and constructive, and the journal's editors offered invaluable guidance. My friends and colleagues at Iqraa's Cairo branch were generous with their time, welcoming of my presence, and patient with my questions. This article is based on fieldwork funded by the Wenner-Gren Foundation, the Fulbright-Hays Program, the National Science Foundation, and the Social Science Research Council, with writing support from the Michigan Society of Fellows. I dedicate this article to the memory of Saba Mahmood, whose scholarship indelibly transformed our understandings of Muslim piety.

1. I use producers as a catchall term to describe the variety of roles and positions held by individuals working at Iqraa's Cairo branch in general and, more specifically, on Hosny's dedicated production team. Throughout the article, I employ pseudonyms for both producers and viewers, and I have changed identifying details.

2. See Lacroix 2009 for a sketch of this figure; see also Gauvain 2013 on Salafi da 'wa networks in Egypt, including a discussion of al-Albani.

3. The piety's movement model of self-cultivation should not be taken as paradigmatic of Muslim religiosity in Egypt (see Mittermaier 2012).

4. Disciplinary interest in theology is increasing, including recent programmatic reflections on what a "theologically engaged anthropology" (Lemons, forthcoming) and "anthropological theologies" (Fountain and Lau 2013) might look like.

5. Salafi-Wahabi preachers and the New Preachers follow two theological schools: Atharism and Ash'arism, respectively. These (internally diverse) schools' conceptions of divine attributes are subjects of elite debate and rarely figure on Islamic television programs; on the history of Athari-Ash'ari disputes, see Qadhi 2016. Interestingly, theologywhose self-described ambit goes beyond speculative theology (kalam) to include jurisprudence, ethics, and creed, as well as ways of interpreting human religious experiences and their sociocultural contexts (Renard 2014) - has been a neglected focus within Islamic studies, as recent anthologies have pointed out (Winter 2008; Schmidtke 2016).

6. The Egyptian state has a tactical attitude toward the Islamic television sector's various orientations, alternating between repudiation and accommodation. Elsewhere, I address Islamic television producers' own concerns about transnational capital, the security state, and increasingly fraught geopolitics (Moll 2017).

7. For introductions to the ethnographic literature on religion and media, see Meyer and Moors 2006, Morgan 2008, and Meyer 2009. De Vries and Weber 2001 offer contributions with a more philosophical approach. For thoughtful reviews, see Stolow 2005, Hirschkind and Larkin 2008, Engelke 2010, and Eisenlohr 2011.

8. In his astute article on the dilemmas of immediacy in sound recordings of Sufi devotional poetry in Mauritius, Patrick Eisenlohr $(2009,285)$ uses the phrase "theologies of mediation" to refer to the tacit theological assumptions shaping peoples' use and understanding of media technologies in religious settings. In contrast, my concern here is with theology as an explicit argumentative terrain for Islamic revivalists' contested claims about media. These claims ontologically orient to mediation as a subject of providential and prophetic proclamation.

9. In 2010, there were 96 religious channels (both Islamic and Christian) broadcasting into Egypt on four satellite operators, 18 of which were transmitting on semi-governmentowned Nilesat. The total number of channels on Nilesat in 2010 was 539. The operating budgets of mainstream entertainment channels dwarf even the most well-funded Islamic satellite channels: for example, MBC's 2011 budget was $\$ 30$ million compared to alResalah's \$5 million.

10. At the same time, to the chagrin of secular artists, the increasingly religious sensibilities of Egypt's middle class act as de facto constraints on what could be feasibly depicted 
on screen without financial risk or public outcry. In general, secularists are less worried about using media to make normative religious claims and more about evaluating media content through religious criteria. See Kubala 2013 for an excellent analysis of how this distinction plays out in a debate Iqraa staged between Egyptian secularists and Islamists.

11. For an in-depth discussion of cosmopolitanism and class in relation to Egyptian youth culture, see Peterson 2011.

12. The stress on natural disposition, din al-fitra, is a hallmark of contemporary Islamic theology (Griffel 2007; March 2015). Islam is such in the sense that all humans are created with a disposition to be Muslim, a disposition that may be corrupted by upbringing or environment. But Islam is a natural religion in another sense: its ethical injunctions are in harmony with human nature. Islam does not ask anything of us that we are not already inclined to perform and value. Divinely mandated rules exist to facilitate the actualization, not repression, of our natural disposition.

13. This valorization of immediacy extends to recitations of the Qur'an itself. Michael Frishkopf $(2009,107)$ shows how the Wahabi-Salafi style deliberately reduces melodic embellishment to sonically emphasize an "unmediated directness" while censuring as bid ' $a$ the long association in Egypt between Qur' anic recitation and musical traditionsa synergy that enabled the professionalization of recitation as artistic pursuit. That the theologies of mediation I encountered within Islamic television production extend to religious practices like recitation suggests a broader "semiotic ideology" (Keane 2018) at work here.

14. Perceptions of immediacy change over time. Media technologies once subject to intense religious scrutiny and debate (e.g., radio) can become routinely accepted as transparently communicative - until their use by new Islamic actors resurfaces their status as transformative human artifacts (see Schulz 2012).

15. These discussions generally elide the robust mainline Salafi critique of jihadi-Salafi movements and political theologies (see Wagemakers 2011).

16. For example, Nadia Fadil and Mayanthi Fernando $(2015,70)$ argue that "the efficacy of norms is not only determined by their realization but also by conscious and unconscious discursive and affective attachments to them, irrespective of one's 'actual' practices." But the question of attachment versus practice is a matter of theological contention among revivalists themselves. For Hosny, a godly person might not be praying regularly but is trying to. This metric of godliness is anathema to Salafi revivalists, for whom, to be Muslim, it is not enough to aspire to regular prayer, or to concede its obligatory nature; one has to actually pray.

17. Writing on the perils (and hopes) of public ethnography, Sherine Hamdy (2017) traces a similar impulse in the reaction of native elites to critical ethnographic analyses of their societies.

18. In 2016, I participated in a roundtable at the annual meeting of the American Anthropological Association, organized by Amira Mittermaier and Omri Elisha, which explored what "an ethnography of God" might look like.

\section{REFERENCES}

Abu-Lughod, Lila

2004 Dramas of Nationhood: The Politics of Television in Egypt. Chicago: University of Chicago Press.

al-Rasheed, Madawi

2006 Contesting the Saudi State: Islamic Voices from a New Generation. New York: University of Cambridge Press.

Armbrust, Walter

2014 "Media Review: al-Da'iyya (The Preacher)." Journal of the American Academy of Religion 82, no. 3: 841-56. https://doi.org/10.1093/jaarel/lfu047.

Asad, Talal

1993 Genealogies of Religion: Discipline and Reasons of Power in Christianity and Islam. Baltimore, Md.: Johns Hopkins University Press. 
1995 “A Comment on Translation, Critique, and Subversion.” In Between Languages and Cultures: Translation and Cross-Cultural Texts, edited by Anuradha Dingwaney and Carol Maier, 325-32. Pittsburgh, Pa.: University of Pittsburgh Press.

1996 "Modern Power and the Reconfiguration of Religious Traditions." Interview. Stanford Electronic Humanities Review 5, no. 1. https://web.stanford.edu/group/ SHR/5-1/text/asad.html.

2006 Formations of the Secular: Christianity, Islam, Modernity. Stanford, Calif.: Stanford University Press.

Atia, Mona

2013 Building a House in Heaven: Pious Neoliberalism and Islamic Charity in Egypt. Minneapolis: University of Minnesota Press.

Baron, Beth

2014 The Orphan Scandal: Christian Missionaries and the Rise of the Muslim Brotherhood. Stanford, Calif.: Stanford University Press.

Bayat, Asef

2002 “Piety, Privilege and Egyptian Youth.” ISIM Newsletter 10, no. 2: 23. http:// hdl.handle.net/1887/16791.

Bialecki, Jon

2014 “Does God Exist in Methodological Atheism? On Tanya Luhrmann's When God Talks Back and Bruno Latour." Anthropology of Consciousness 25, no. 1: 32-52. https://doi.org/10.1111/anoc. 12017.

Boyer, Dominic

2012 "From Media Anthropology to the Anthropology of Mediation." In The Sage Handbook of Social Anthropology, Volume 2, edited by Richard Fardon, Olivia Harris, Trevor H. J. Marchand, Mark Nuttall, Cris Shore, Veronica Strang, and Richard A. Wilson, 411-422. Los Angeles: SAGE.

Brinton, Jacquelene G.

2015 Preaching Islamic Renewal: Religious Authority and Media in Contemporary Egypt. Berkeley: University of California Press.

Chih, Rachida, and Catherine Mayeur-Jaouen

2002 “Le cheikh Cha'râwî, le pouvoir, et la télévision: l'homme qui a donné un visage au Coran." In Saints et héros du Moyen-Orient contemporain, edited by Catherine Mayeur-Jaouen, 189-209. Paris: Maisonneuve et Larose.

Chittick, William C.

2008 “Worship." In The Cambridge Companion to Classical Islamic Theology, edited by Tim Winter, 218-36. New York: Cambridge University Press.

Commins, David

2009 The Wahabi Mission and Saudi Arabia. New York: I. B. Tauris.

Deeb, Lara, and Mona Harb

2013 Leisurely Islam: Negotiating Geography and Morality in Shi'ite South Beirut. Princeton, N.J.: Princeton University Press.

de Vries, Hent, and Samuel Weber, eds.

2001 Religion and Media. Stanford, Calif.: Stanford University Press.

Eisenlohr, Patrick

2009 "Technologies of the Spirit: Devotional Islam, Sound Reproduction, and the Dialectics of Mediation and Immediacy in Mauritius." Anthropological Theory 9, no. 3: 273-96. https://doi.org/10.1177/1463499609346983.

2011 "Introduction: What is a Medium? Theologies, Technologies, Aspirations." Social Anthropology 19, no. 1: 1-5. https://doi.org/10.1111/j.1469-8676.2010. 00134.x.

Engelke, Matthew

2010 "Religion and the Media Turn: A Review Essay." American Ethnologist 37, no. 2: 371-79. https://doi.org/10.1111/j.1548-1425.2010.01261.x.

2013 God's Agents: Biblical Publicity in Contemporary England. Berkeley: University of California Press. 
Fadil, Nadia, and Mayanthi Fernando

2015 "Rediscovering the 'Everyday' Muslim: Notes on an Anthropological Divide." HAU 5, no. 2: 59-88. https://doi.org/10.14318/hau5.2.005.

Field, Nathan, and Ahmed Hamam

2009 "Salafi Satellite TV in Egypt." Arab Media and Society, no. 8. http:// www. arabmediasociety. com/?article $=712$.

Fierro, Maribel

1992 “The Treatises against Innovations (kutub al-bida).” Der Islam 69, no. 2: 204 236. https://doi.org/10.1515/islm.1992.69.2.204.

Fountain, Philip, and Sin Wen Lau

2013 “Anthropological Theologies: Engagements and Encounters.” Australian Journal of Anthropology 24, no. 3: 227-34. https://doi.org/10.1111/taja.12048.

Frishkopf, Michael

2009 “Mediated Qur'anic Recitations and the Contestation of Islam in Contemporary Egypt." In Music and the Play of Power in the Middle East, North Africa, and Central

Gauvain, Richard Asia, edited by Laudan Nooshin, 75-114. Burlington, Vt.: Ashgate.

2013 Salafi Ritual Purity: In the Presence of God. New York: Routledge.

Ginsburg, Faye, Lila Abu-Lughod and Brian Larkin, eds.

2002 Media Worlds: Anthropology on New Terrain. Berkeley: University of California Press.

Green, Nile

2014 Terrains of Exchange: Religious Economies of Global Islam. New York: Oxford University Press.

Gregory, Brad S.

2012 The Unintended Reformation: How a Religious Revolution Secularized Society. Cambridge, Mass.: Harvard University Press.

Griffel, Frank

2007 “The Harmony of Natural Law and Shari'a in Islamist Theology.” In Shari'a: Islamic Law in the Contemporary Context, edited by Abbas Amanat and Frank Griffel, 38-61. Stanford, Calif.: Stanford University Press.

Haenni, Patrick, and Husam Tammam

2003 "Chat Shows, Nashid Groups, and Lite Preaching: Egypt's Air-Conditioned Islam.” Le Monde Diplomatique, September. https://mondediplo.com/2003/09/

Hamdy, Sherine 03egyptislam.

2017 “How Publics Shape Ethnographers: Translating across Divided Audiences.” In If Truth Be Told: The Politics of Public Ethnography, edited by Didier Fassin, 287-

Hirschkind, Charles 309. Durham, N.C.: Duke University Press.

2006 The Ethical Soundscape: Cassette Sermons and Islamic Counterpublics. New York: Columbia University Press.

2012 "Experiments in Devotion Online: The YouTube Khuṭba." International Journal of Middle East Studies 44, no. 1: 5-21. http://www.jstor.org/stable/41474978.

Hirschkind, Charles, and Brian Larkin

2008 "Introduction: Media and the Political Forms of Religion." Social Text 26, no. 3: 1-9. https://doi.org/10.1215/01642472-2000-001.

Hoesterey, James Bourk

2016 Rebranding Islam: Piety, Prosperity and a Self-Help Guru. Stanford, Calif.: Stanford University Press.

Keane, Webb

2014 "Ethics as Piety." Numen 61, nos. 2-3: 221-36. https://doi.org/10.1163/ $15685276-12341317$.

2018 “On Semiotic Ideology.” Signs and Society 6, no. 1: 64-87. https://doi.org/ 10.1086/695387. 
Kubala, Patricia

2013 “'You Will (Not) Be Able to Take Your Eyes Off It!': Mass-Mediated Images and Politico-Ethical Reform in the Egyptian Islamic Revival.” In Visual Culture in the Modern Middle East: Rhetoric of the Image, edited by Christiane Gruber and Sune Haugbolle, 82-100. Bloomington: Indiana University Press.

Lacroix, Stéphane

2009 "Between Revolution and Apoliticism: Nasir al-Din al-Albani and His Impact on the Shaping of Contemporary Salafism.” In Global Salafism: Islam's New Religious Movement, edited by Roel Meijer, 58-80. New York: Columbia University Press.

Larkin, Brian

2008 "Ahmed Deedat and the Forms of Islamic Evangelism." Social Text 26, no. 3: 101-121. https: / / doi.org/10.1215/01642472-2008-006.

2015 "Binary Islam: Media and Religious Movements in Nigeria." In New Media and Religious Transformations in Africa, edited by Rosalind I. J. Hackett and Benjamin Lauzière, Henri F. Soares, 63-81. Bloomington: Indiana University Press.

2016 The Making of Salafism: Islamic Reform in the Twentieth Century. New York: Columbia University Press.

Lemons, J. Derrick, ed.

Forthcoming Theologically Engaged Anthropology: Social Anthropology and Theology in Conversation. New York: Oxford University Press.

Mahmood, Saba

2005 Politics of Piety: The Islamic Revival and the Feminist Subject. Princeton, N.J.: Princeton University Press.

March, Andrew F.

2015 "Naturalizing Shar̄'a: Foundationalist Ambiguities in Modern Islamic Apologetics." Islamic Law and Society 22, nos. 1-2: 45-81. https://doi.org/ 10.1163/15685195-02212p02.

Meyer, Birgit

2009 Aesthetic Formations: Media, Religion, and the Senses. New York: Palgrave Macmillan.

2011 "Mediation and Immediacy: Sensational Forms, Semiotic Ideologies, and the Question of the Medium.” Social Anthropology 19, no. 1: 23-39. https://doi.org/ 10.1111/j.1469-8676.2010.00137.x.

Meyer, Birgit, and Annelies Moors, eds.

2006 Religion, Media and the Public Sphere. Bloomington: Indiana University Press. Mittermaier, Amira

2012 "Dreams from Elsewhere: Muslim Subjectivities Beyond the Trope of SelfCultivation." Journal of the Royal Anthropological Institute 18, no. 2: 247-65. https://doi.org/10.1111/j.1467-9655.2012.01742.x.

Moll, Yasmin

2017 "The Moral Economy of Islamic Television: Panics and its Perils." POMEPS Studies, no. 23: 18-21. https://pomeps.org/2017/02/10/the-new-islamicmedia.

Morgan, David, ed.

2008 Key Words in Religion, Media, and Culture. New York: Routledge.

Ortner, Sherry B.

1995 "Resistance and the Problem of Ethnographic Refusal." Comparative Studies in Society and History 37, no. 1: 173-93. https://doi.org/10.1017/ S0010417500019587.

Peterson, Mark Allen

2011 Connected in Cairo: Growing Up Cosmopolitan in the Modern Middle East. Bloomington: Indiana University Press. 
Qadhi, Yasir

2016 "Salafi-Ash 'ari Polemics of the Third and Fourth Islamic Centuries." Muslim World 106, no. 3: 433-47. https://doi.org/10.1111/muwo.12161.

Renard, John, ed.

2014 Islamic Theological Themes: A Primary Source Reader. Berkeley: University of California Press.

Rispler, Vardit

1991 "Toward a New Understanding of the Term bid'a." Der Islam 68, no. 2: 32028. https://doi.org/10.1515/islm.1991.68.2.320.

Robbins, Joel

2006 "Anthropology and Theology: An Awkward Relationship?" Anthropological Quarterly 79, no. 2: 285-94. https://doi.org/10.1353/anq.2006.0025.

Robbins, Joel, and Matthew Engelke

2010 “Introduction.” South Atlantic Quarterly 109, no. 4: 623-31. https://doi.org/ 10.1215/00382876-2010-009.

Schielke, Samuli

2009 "Being Good in Ramadan: Ambivalence, Fragmentation, and the Moral Self in the Lives of Young Egyptians." Journal of the Royal Anthropological Institute 15, S1: S24 40. https://doi.org/10.1111/j.1467-9655.2009.01540.x.

2010 "Second Thoughts about the Anthropology of Islam, or, How to Make Sense of Grand Schemes in Everyday Life.” Zentrum Moderner Orient Working Papers, no. 2. http://d-nb.info/1019243724/34.

2015 "Living with Unresolved Differences: A Reply to Fadil and Fernando." HAU 5, no. 2: 89-92. https://doi.org/10.14318/hau5.2.006.

Schmidtke, Sabine, ed.

2016 The Oxford Handbook of Islamic Theology. New York: Oxford University Press.

Schulz, Deborah

2012 "Reconsidering Muslim Authority: Female 'Preachers' and the Ambiguities of Radio-Mediated Sermonizing in Mali." In Radio Fields: Anthropology and Wireless Sound in the Twenty-First Century, edited by Lucas Bessire and Daniel Fisher, 108123. New York: New York University Press.

Spadola, Emilio

2013 The Calls of Islam: Sufis, Islamists, and Mass Mediation in Urban Morocco. Bloomington: Indiana University Press.

Starrett, Gregory

2010 "The Varieties of Secular Experience." Comparative Studies in Society and History 52, no. 3: 626-51. https://doi.org/10.1017/S0010417510000332.

Stolow, Jeremy

2005 “Religion and/as Media.” Theory, Culture, and Society 22, no. 4: 119-45. https:// doi.org/10.1177/0263276405054993.

van Nieuwkerk, Karin

2013 Performing Piety: Singers and Actors in Egypt's Islamic Revival. Austin: University of Texas Press.

van Nieuwkerk, Karin, ed.

2011 Muslim Rap, Halal Soaps, and Revolutionary Theater: Artistic Developments in the Muslim World. Austin: University of Texas Press.

Wagemakers, Joas

2009 'The Transformation of a Radical Concept: Al-wala' wa-l-bara' in the Ideology of Abu Muhammad al-Maqdisi." In Global Salafism: Islam's New Religious Movement, edited by Roel Meijer, 81-106. New York: Columbia University Press.

2011 “'Seceders' and 'Postponers'?: An Analysis of the 'Khawarij' and 'Murji'a' Labels in Polemical Debates between Quietist and Jihadi-Salafis.” In Contextualizing Jihadi Thought, edited by Jeevan Deol and Zaheer Kazmi, 145-64. New York: Columbia University Press. 
2012 "The Enduring Legacy of the Second Saudi State: Quietist and Radical Wahhabi Contestations of al-Walä' wa-1-Barä', International Journal of Middle East Studies 44, no. 1: 93-110. https://doi.org/10.1017/S0020743811001267.

Winegar, Jessica

2014 "Civilizing Muslim Youth: Egyptian State Culture Programs and Islamic Television Preachers." Journal of the Royal Anthropological Institute 20, no. 3: 44565. https://doi.org/10.1111/1467-9655.12116.

Winter, Tim, ed.

2008 The Cambridge Companion to Classical Islamic Theology. New York: Cambridge University Press.

Winter, T. J.

2009 "The Poverty of Fanaticism." In Islam, Fundamentalism, and the Betrayal of Tradition: Essays by Western Muslim Scholars, edited by Joseph E. B. Lumbard, 301-313. Revised and expanded edition. Bloomington, Ind.: World Wisdom. 